\title{
Orális antikoagulánssal kezelt pitvarfibrilláló betegek terápiahüsége a mindennapokban
}

\author{
Simonyi Gábor dr. ${ }^{1}$ - Paksy András dr. ${ }^{2}$ \\ Várnai Réka dr. ${ }^{3}$ - Medvegy Mihály dr. ${ }^{4}$ \\ ${ }^{1}$ Szent Imre Egyetemi Oktatókórház, Anyagcsere Központ, Budapest \\ ${ }^{2}$ Aesculap Akadémia, Budapest \\ ${ }^{3}$ Pécsi Tudományegyetem, Általános Orvostudományi Kar, Alapellátási Intézet, Pécs \\ ${ }^{4}$ Pest Megyei Flór Ferenc Kórház, III. Belgyógyászat - Kardiológiai Osztály, Kistarcsa
}

\begin{abstract}
Bevezetés: A nonvalvularis pitvarfibrilláció ( $\mathrm{PF}$ ) orális antikoagulánssal (OAK) történő kezelésekor a terápiahüség igen jelentős tényező a stroke-prevencióban.

Célkitüzés: OAK-terápiában részesülő, PF-ban szenvedő betegek esetében az antikoaguláns-terápiák (K-vitamin-antagonista [KVA] és az új orális antikoagulánsok [NOAK]) egyéves perzisztenciájának vizsgálata.

Módszer: A szerzők pitvarfibrilláció-indikációban a Nemzeti Egészségbiztosítási Alapkezelő adatbázisában, 2016 második félévében (bevonási időszak) valamilyen orális antikoaguláns- (OAK $=\mathrm{KVA} / \mathrm{NOAK})$ terápiában részesülő betegek perzisztenciáját vizsgálták a vényforgalmi adatok felhasználásával, az első kiváltástól számított 12 hónapig (60 napos 'grace' periódussal).

Eredmények: A bevonási kritériumoknak 122870 beteg felelt meg. A betegek közül 18650 beteg kezdett újonnan, míg 104220 beteg volt már valamelyik OAK-terápián. Az új betegek között a NOAK-terápia egyéves perzisztenciája 65,7\%, míg a KVA-terápiáé 39,0\% volt $(\mathrm{p}<0,001)$. A már kezelt betegek esetében az egyéves perzisztencia a NOAK esetében $72,6 \%$-nak, a KVA esetében $53,9 \%$-nak bizonyult $(\mathrm{p}<0,001)$. Az új betegeknél a NOAK-terápián belül a rivaroxaban egyéves perzisztenciája $65,7 \%$, az apixabané 62,6\%, a dabigatráné $59,2 \%$ volt (logrank p $<0,001$ minden összehasonlításban, kivéve rivaroxaban vs. apixaban: $\mathrm{p}=0,017$, dabigatrán vs. apixaban: $\mathrm{p}<0,01)$. A már NOAK-kal kezelt betegek egyéves perzisztenciája a rivaroxaban esetében $73,4 \%$, az apixaban esetében $68,0 \%$, a dabigatrán esetében $68,4 \%$ volt (logrank p<0,001 minden összehasonlításban, kivéve apixaban vs. dabigatrán, NS).

Következtetések: PF-ban a KVA-terápiához képest a NOAK-ok egyéves perzisztenciája szignifikánsan magasabb volt (új betegeknél és már kezelteknél). A NOAK-ok közül a rivaroxaban egyéves perzisztenciája volt a legelőnyösebb mindkét vizsgált betegcsoportban;
\end{abstract}

Orv Hetil. 2020; 161(20): 839-845.

Kulcsszavak: pitvarfibrilláció, K-vitamin-antagonisták, adherencia, új orális antikoagulánsok

\section{Real-world adherence to oral anticoagulants in atrial fibrillation}

Introduction: In the treatment of non-valvular atrial fibrillation (AF) with oral anticoagulant (OAC), the patients' adherence to therapy is a very important factor in stroke prevention.

Aim: To investigate the one-year persistence of different OAC therapies (vitamin $\mathrm{K}$ antagonist [VKA] and new oral anticoagulants [NOAC]) in patients with $\mathrm{AF}$.

Method: The authors investigated the persistence of oral anticoagulant $(\mathrm{OAC}=\mathrm{VKA} / \mathrm{NOAC})$ in atrial fibrillation using the National Health Insurance Fund of Hungary prescriptions database on pharmacy claims between June 1, 2016 and December 31, 2016.

Results: 122870 patients met the inclusion criteria. 18650 patients started OACs therapy newly (therapy-naïve group), while 104220 were already on one of the OACs. Among new patients, the one-year persistence of NOACs was $65.7 \%$ and that of VKA was $39.0 \%(\mathrm{p}<0.001)$. The one-year persistence rate was $72.6 \%$ for NOAC and $53.9 \%$ for VKA $(\mathrm{p}<0.001)$ in patients already on OACs. In the therapy-naïve group, the one-year persistence to rivaroxaban was $65.7 \%$. To apixaban it was $62.6 \%$, and to dabigatran it was $59.2 \%$ (logrank $p<0.001$ in all comparisons except rivaroxaban vs. apixaban: $\mathrm{p}=0.017$, and dabigatran vs. apixaban: $\mathrm{p}<0.01)$. The one-year persistence rate of patients 
treated with NOACs was $73.4 \%$ to rivaroxaban, $68.0 \%$ to apixaban, and $68.4 \%$ to dabigatran (logrank p<0.001 in all comparisons except apixaban vs. dabigatran, NS).

Conclusions: The one-year persistence of NOACs was significantly higher in AF compared to VKA therapy (in therapy-naïve and in already treated patients, too). Among the NOACs, rivaroxaban has the best one-year persistence in all patient populations.

Keywords: atrial fibrillation, vitamin K antagonists, adherence, novel oral anticoagulants

Simonyi G, Paksy A, Várnai R, Medvegy M. [Real-world adherence to oral anticoagulants in atrial fibrillation]. Orv Hetil. 2020; 161(20): 839-845.

(Beérkezett: 2020. január 12.; elfogadva: 2020. február 12.)

\begin{abstract}
Rövidítések
$\mathrm{BNO}=$ betegségek nemzetközi osztályozása $; \mathrm{CI}=$ (confidence interval) konfidenciaintervallum; ESC $=($ European Society of Cardiology) Európai Kardiológusok Társasága; HR = (hazard ratio) kockázati arány; $\mathrm{INR}=$ (international normalized ratio) nemzetközi normalizált arány; KVA = K-vitamin-antagonista; NEAK = Nemzeti Egészségbiztosítási Alapkezelő; NOAK = (novel oral anticoagulant) új orális antikoaguláns; OAK $=$ (oral anticoagulant) orális antikoaguláns; $\mathrm{PF}=$ pitvarfibrilláció
\end{abstract}

Míg korábban pitvarfibrillációban (PF) a stroke megelőzésére a per os terápiában a K-vitamin-antagonisták (KVA-k) játszották a fószerepet, addig jelenleg az ESC legfrissebb ajánlásában - fóleg új antikoaguláns-terápia indításakor - az új orális antikoagulánsok alkalmazását szorgalmazzák. Mindezt a legmagasabb szintü evidenciával (I. osztály, A-szintú evidencia) javasolják, amelynek hátterében az új orális antikoaguláns (NOAK)-terápia egyértelmü előnyei állnak a KVA-kkal szemben [1-3].

A PF hazánkban is jelentős számú beteget érint, mivel egy korábbi felmérésben teljes gyakoriságát 2,95\%-nak találták, ami mintegy 300000 beteget jelentett [4]. A PF-betegeknél lényegében csak a 100\%-os adherencia jelentheti a lehető legnagyobb stroke-prevenciót, mivel minden 10\%-os adherenciacsökkenés a stroke és a halálozás 13\%-os emelkedését okozza. Minden OAK-terápia során - hatásossági és biztonságossági szempontból elengedhetetlen a gyógyszerszedési utasítások pontos betartása. A rossz betegadherencia esetében nő a stroke/ halálozás kockázata [5].

Korábbi vizsgálatunkban elemeztük a Nemzeti Egészségbiztosítási Alapkezelő (NEAK) vénykiváltási adatainak retrospektív feldolgozásával a korábban már orális antikoaguláns $(\mathrm{OAK})$-terápián lévő PF-betegek egyéves perzisztenciáját [6]. Jelen dolgozatunkban e munkát folytatjuk a 2016-2017. év adatainak feldolgozásával.

\section{Célkitüzések}

Vizsgálatunkban pitvarfibrilláció-indikációban a különböző OAK- (NOAK- és KVA-) terápiák egyéves terápiahüségének elemzését tüztük ki célul, korábban már
OAK-kal kezelt és ilyen típusú terápiában nem részesült, új betegeknél. A hatóanyagcsoportok egyéves perzisztenciájára vonatkozó adatokon kívül az OAK-terápia szempontjából fontos más paramétereket (például átlagos gyógyszerszedési idő, az egyes NOAK-hatóanyagok elhagyásának rátája) is vizsgáltuk.

\section{Betegek és módszer}

A NEAK adatbázisát elemző retrospektív vizsgálatunkban azokat a betegeket választottuk ki, akik 2016 második félévében (a június 1-től december 31 -ig terjedő időszakban) pitvarfibrilláció $(\mathrm{BNO}=\mathrm{I} 10 \mathrm{H} 0)$ indikációjában bármilyen orális antikoaguláns- (KVA- vagy NOAK-) terápiában részesültek. E betegek közül új betegeknek tekintettük azokat, akiknek a bevonási időszakot megelőzően, a vizsgálati időszakban történt első kiváltási dátumhoz képest visszamenőleg egy 12 hónapos időtartamban nem volt vénykiváltásuk az adott hatóanyagokból (bármely NOAK vagy KVA).

Kezelt betegeknek azokat tekintettük, akiknek a bevonási időszakot megelőzően, a vizsgálati időszakban történt kiváltási dátumhoz képest visszamenóleg egy 12 hónapos időtartamban volt vénykiváltásuk (bármely NOAK vagy KVA). A KVA-terápiában részesülő betegek receptkiváltásait nem bontottuk le hatóanyagokra (warfarin vagy acenokumarol), csak csoportszinten elemeztük. A NOAK-terápiás csoportot a vizsgálati időszakban forgalomban lévő és támogatottan kiváltható hatóanyagok szintjén is vizsgáltuk.

A receptkiváltásokat minden betegnél 14 hónapig, de legkésőbb 2018. február 28-ig követtük. Kizártuk elemzésünkből a követési időszak alatt elhalálozott betegeket. 60 napos gyógyszerkihagyással ('grace' periódus) vizsgáltuk, hogy a bevonási kritériumoknak megfelelt és követett betegek mekkora aránya maradt az adott OAKterápián a két fó (új betegek, már kezelt betegek) betegcsoportban. A NEAK adatbázisában a receptkiváltási adatok 30 napos időközönként voltak elérhetők.

Az orális antikoagulánssal történő kezelés perzisztenciájának modellezésére a túlélés-analízis klasszikus eszköztárát alkalmaztuk úgy, hogy a „túlélési idő” a gyógy- 


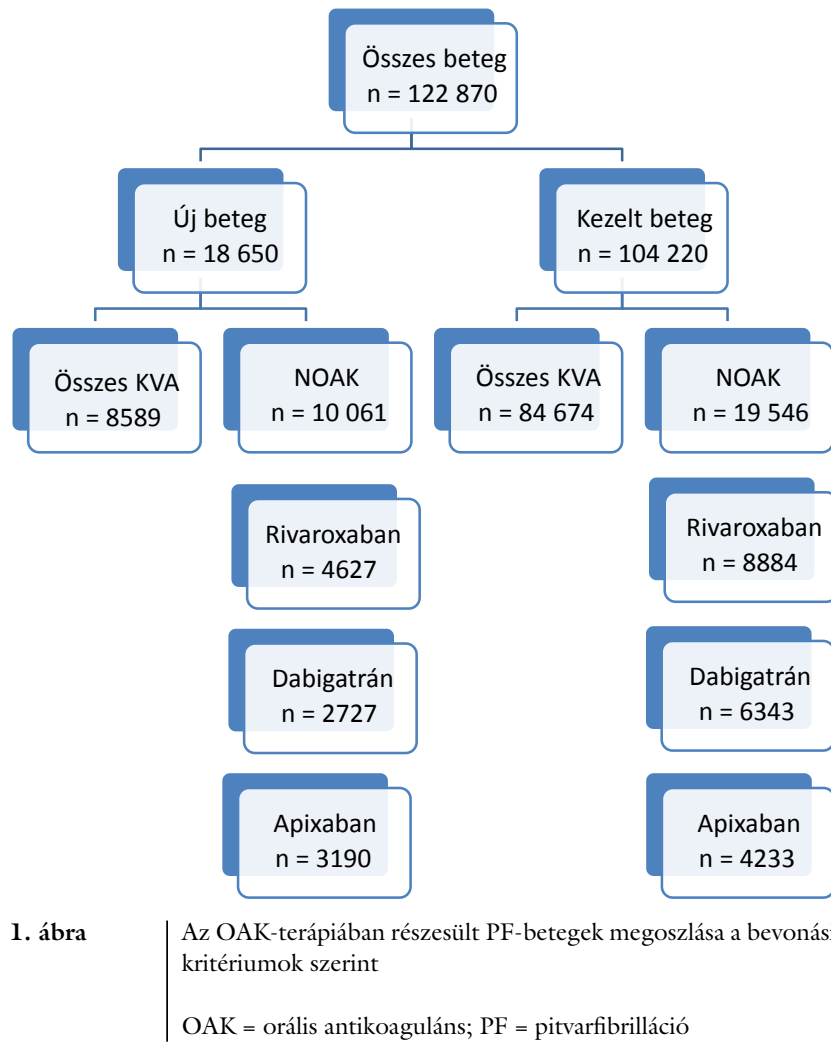

szer szedésének kezdetétôl egészen az annak elhagyásáig eltelt idő volt. A perzisztencia 30 naponkénti változásának alakulását az egyedi gyógyszerszedési (vénykiváltási) adatok alapján Kaplan-Meier-módszerrel elemeztük. Hatóanyagcsoportonként, illetve hatóanyagonként meghatároztuk az átlagos gyógyszerszedési időt és annak 95\%-os konfidenciaintervallumát.

Az össz-NOAK- vs. össz-KVA-csoport, másrészt a rivaroxaban- vs. össz-KVA-, rivaroxaban- vs. dabigatrán-, rivaroxaban- vs. apixabancsoport közötti perzisztencia- különbségek statisztikai összehasonlítása logrank módszerrel történt.

A hatóanyagcsoportok perzisztenciájának összehasonlításakor a legjobb perzisztenciával rendelkező hatóanyaghoz viszonyított hazard ratio (HR) számítása az egyedi gyógyszerszedési adatok alapján Cox-regresszió alkalmazásával történt [7-9].

\section{Eredmények}

A NEAK adatbázisában 122870 olyan beteget találtunk, aki a 2016. év második felében valamilyen OAK-terápiában részesült. E betegek közül mindösszesen 18650 beteg kapott újonnan OAK-terápiát, míg 104220 beteg tartozott a már OAK-kal kezelt csoportba. Az új betegek közül 8589 szedett valamilyen KVA-hatóanyagot (KVA összes), míg 10061 beteg részesült valamelyik NOAK(NOAK összes) terápiában. A NOAK-ot szedők közül 3190 kapott apixaban-, 2727 dabigatrán-, míg 4627 rivaroxabanterápiát.

A bevonási kritériumok alapján már OAK-kal kezeltnek 104220 beteg számított, akik közül 84674 részesült KVA-terápiában, míg 19546 beteg szedett NOAKot. A NOAK-terápián lévők közül 8884 beteg apixabant, 6343 dabigatránt, míg 4233 rivaroxabant szedett (1. ábra). Az edoxaban PF-indikációban ebben az időszakban nem volt elérhetô támogatottan, ezért elemzésünkben nem szerepeltettük.

$\mathrm{Az}$ újonnan OAK-terápiát kezdők esetében az egyéves KVA-perzisztencia 39,0\%, míg a NOAK-terápiáé 65,7\% volt (2. ábra), ami 26,7 százalékpontos különbséget jelentett a NOAK javára. A KVA-terápia elhagyásának kockázata több mint kétszeres volt a NOAK-terápiával összevetve ( $\mathrm{HR}=2,23$ [95\% CI 2,13-2,32], logrank $\mathrm{p}<0,001)$. A NOAK-terápián belül a rivaroxaban egyéves perzisztenciája $65,7 \%$, az apixabané $62,6 \%$, míg a da-

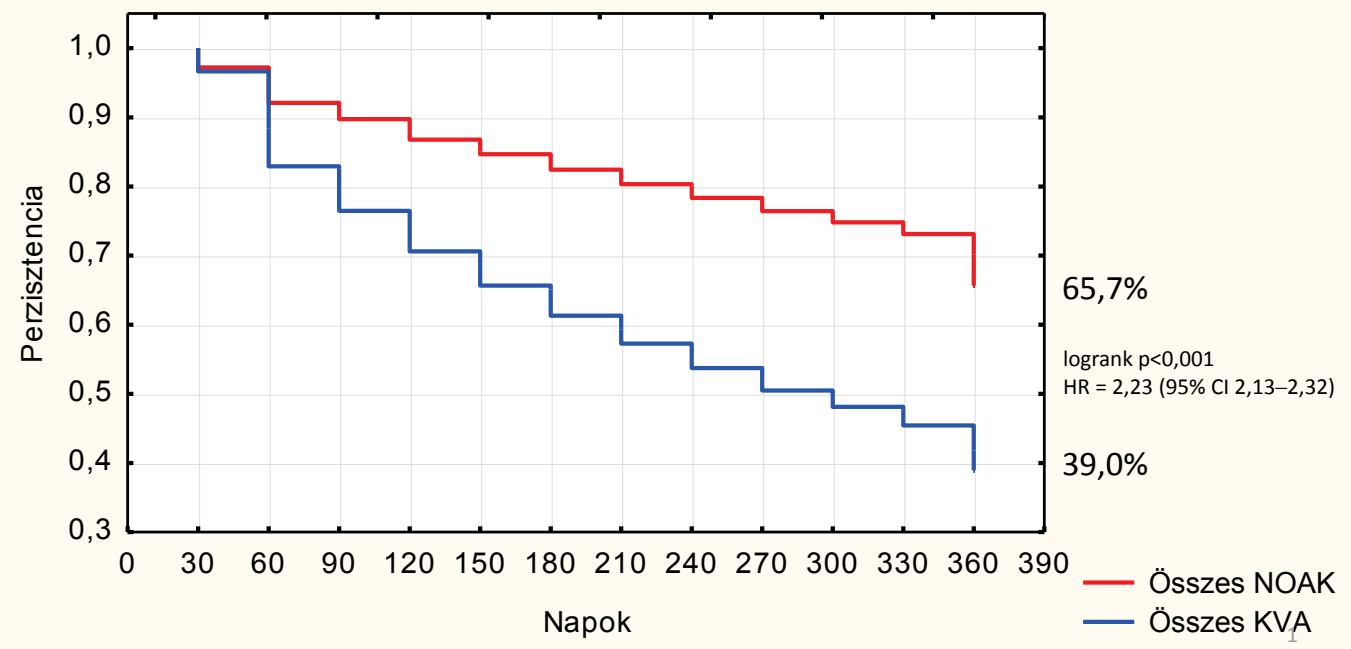

2. ábra

Az egyéves OAK-perzisztencia az új betegeknél (NOAK vs. KVA) $(\mathrm{n}=18$ 650)

$\mathrm{CI}=$ konfidenciaintervallum; $\mathrm{HR}=$ kockázati arány $\mathrm{KVA}=\mathrm{K}$-vitamin-antagonista; $\mathrm{NOAK}=$ új orális antikoaguláns; OAK = orális antikoaguláns 
logrank $p<0,001$ minden összehasonlításban, kivéve Rivaroxaban vs. Apixaban: $p=0,017$, Dabigatrán vs. Apixaban: $p<0,01$

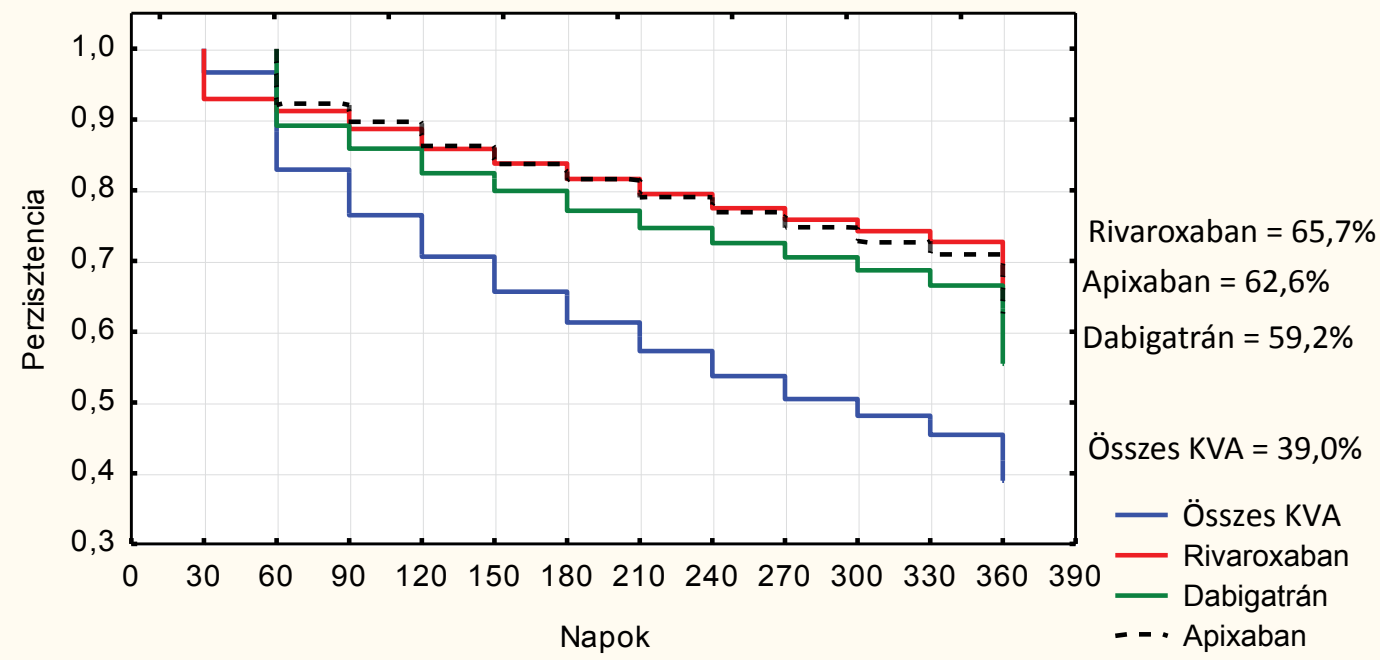

3. ábra

$\mid \begin{aligned} & \text { Az egyéves OAK-perzisztencia (NOAK-hatóanyagok és KVA) az új betegeknél ( } \mathrm{n}=18650 \text { ) } \\ & \mathrm{KVA}=\mathrm{K} \text {-vitamin-antagonista; NOAK = új orális antikoaguláns; OAK = orális antikoaguláns }\end{aligned}$

bigatráné 59,2\% volt. Az egyes NOAK-hatóanyagcsoportok és a KVA-terápia közötti perzisztenciakülönbség minden összehasonlításban szignifikánsnak bizonyult (3. ábra).

A 360 napra korlátozott átlagos gyógyszerszedési idő 301 [95\% CI 298-304] nap volt a rivaroxaban, 302 [95\% CI 299-306] nap az apixaban, 290 [95\% CI 286294] nap a dabigatrán, míg 243 [95\% CI 240-245] nap a KVA-k esetén (4. ábra).

A legjobb egyéves perzisztenciával rendelkező rivaroxabanhoz képest $(\mathrm{HR}=1,00)$ a gyógyszerelhagyás kockázata az apixabant szedőknél 9\% (HR = 1,09 [95\% CI 1,02-1,16], p =0,017), a dabigatráncsoportban $24 \%$

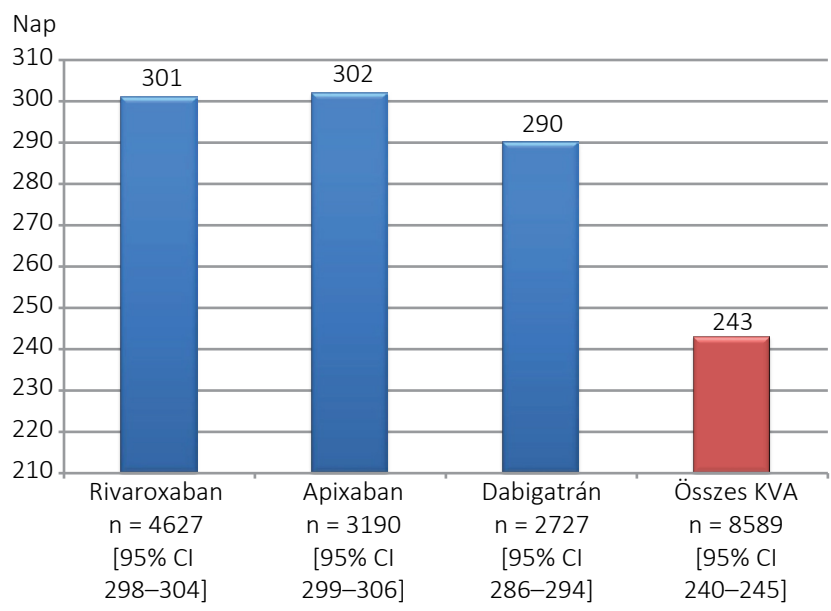

4. ábra

A gyógyszerszedés átlagos ideje (NOAK-hatóanyagok és KVA) az új betegeknél ( $\mathrm{n}=18650$ )

$\mathrm{CI}=$ konfidenciaintervallum $; \mathrm{KVA}=\mathrm{K}$-vitamin-antagonista NOAK = új orális antikoaguláns
$(\mathrm{HR}=1,24$ [95\% CI 1,15-1,32], p<0,001), míg a KVA-t szedőknél több mint kétszeres $(\mathrm{HR}=2,20$ [95\% CI 2,09-2,32], $\mathrm{p}<0,001)$ volt (5. ábra). Mindez azt jelentette, hogy a rivaroxabanhoz képest a többi NOAK-hatóanyag, illetve a KVA-terápia elhagyásának kockázata szignifikánsan magasabb volt az OAK-terápiát újonnan elindítóknál.

A már korábban OAK-terápiában részesülteknél az egyéves KVA-perzisztencia 53,9\%, míg a NOAK-terápiáé $72,6 \%$ volt (6. ábra), ami 18,7 százalékpontos különbséget jelentett a NOAK-terápia javára e betegcsoportban. A KVA-terápia elhagyásának kockázata mintegy kétszeres volt a NOAK-terápiával összevetve $(\mathrm{HR}=1,92$ [95\% CI 1,88-1,97], logrank p<0,001). A NOAK-terápián belül a rivaroxaban egyéves perzisztenciája 73,4\%, az apixabané $68,0 \%$, míg a dabigatráné $68,4 \%$ volt. Az egyes NOAK-készítmények és a KVA-terápia közötti perzisztenciakülönbség minden összehasonlításban (kivéve az apixaban vs. dabigatrán, NS) szignifikánsnak bizonyult (7. ábra).

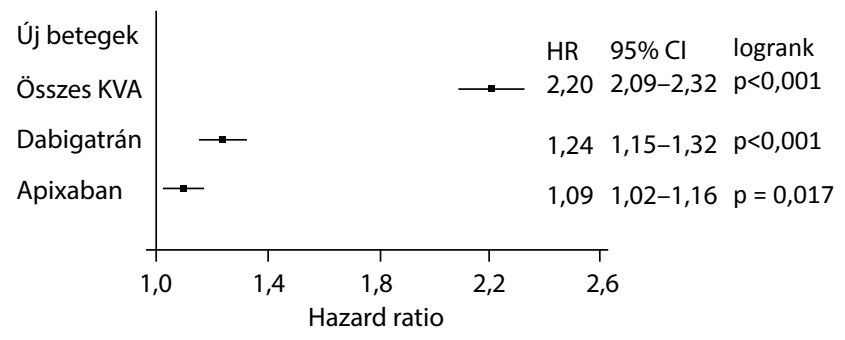

5. ábra Az OAK-terápia elhagyásának kockázata új betegeknél (n = 18650 ; referencia $[\mathrm{HR}=1,00]$ a rivaroxaban)

$\mathrm{CI}=$ konfidenciaintervallum; $\mathrm{HR}=$ kockázati arány; OAK = orális antikoaguláns 


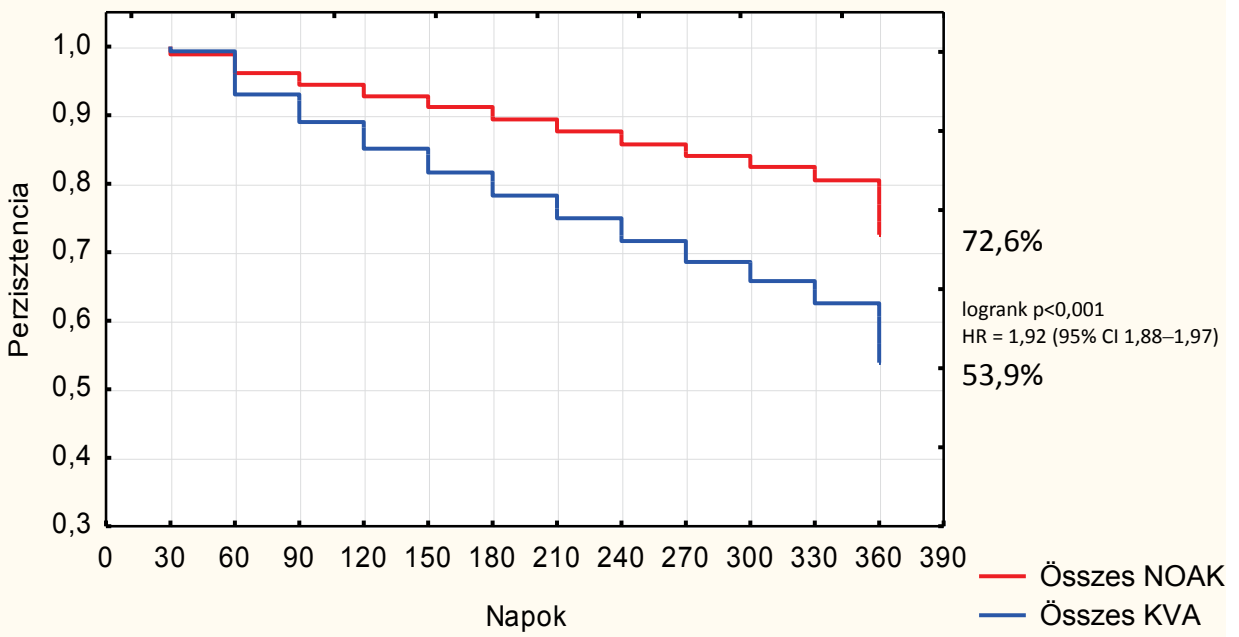

6. ábra

A korábban OAK-terápiában részesültek egyéves perzisztenciája (NOAK vs. KVA) $(\mathrm{n}=104$ 220)

$\mathrm{CI}=$ konfidenciaintervallum; $\mathrm{HR}=$ kockázati arány $\mathrm{KVA}=\mathrm{K}$-vitamin-antagonista; $\mathrm{NOAK}=$ új orális antikoaguláns; OAK $=$ orális antikoaguláns

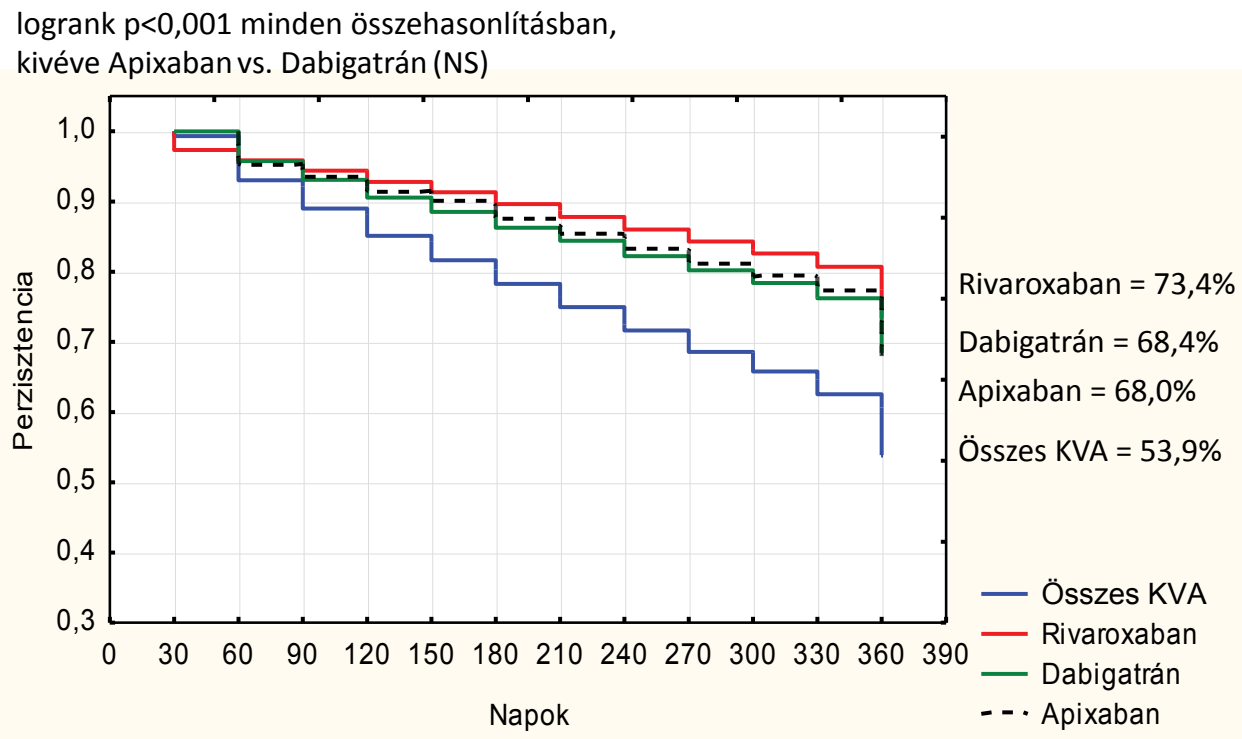

7. ábra

Az egyéves perzisztencia az előzetesen már OAK-kal (NOAK-hatóanyagok és KVA) kezelt betegeknél ( $\mathrm{n}=104220)$

$\mathrm{KVA}=\mathrm{K}$-vitamin-antagonista; $\mathrm{NOAK}=$ új orális antikoaguláns; $\mathrm{NS}=$ nem szignifikáns; $\mathrm{OAK}=$ orális antikoaguláns

A 360 napra korlátozott átlagos gyógyszerszedési idő 325 [95\% CI 323-327] nap volt a rivaroxaban, 319 [95\% CI 317-322] nap az apixaban, 317 [95\% CI 315319] nap a dabigatrán, míg 291 [95\% CI 290-292] nap a KVA-k esetén (8. ábra).

Ebben a betegcsoportban is a rivaroxaban rendelkezett a legjobb egyéves perzisztenciával, ezért ezt kezeltük referenciaként $(\mathrm{HR}=1,00)$. A rivaroxabanhoz képest a gyógyszerelhagyás kockázata az apixabannal kezeltekben 23\%-kal ( $\mathrm{HR}=1,23$ [95\% CI 1,15-1,32], $\mathrm{p}<0,001)$, a dabigatráncsoportban $22 \%$-kal $(\mathrm{HR}=1,22$ [95\% CI 1,15-1,30], p<0,001), míg a KVA-t szedóknél majdnem kétszeresen ( $\mathrm{HR}=1,98$ [95\% CI 1,92-2,04], $\mathrm{p}<0,001$ ) volt magasabb (9. ábra). Mindez azt jelentet- te, hogy a korábban már OAK-terápiában részesültek csoportjában a rivaroxabanhoz képest a többi NOAK-, illetve a KVA-terápia elhagyásának kockázata szignifikánsan kifejezettebb volt.

\section{Megbeszélés}

Hazai „real world” vizsgálatunkban igazoltuk, hogy a PF-indikációban alkalmazott NOAK-terápia mind az új, mind a korábban már OAK-kal kezelt betegekben szignifikánsan magasabb terápiahűséggel jár a KVA-terápiához képest. Új betegek esetében 26,7 százalékponttal, míg a már kezelteknél 18,7 százalékponttal bizonyult előnyösebbnek a NOAK-terápia. A KVA elhagyásának 


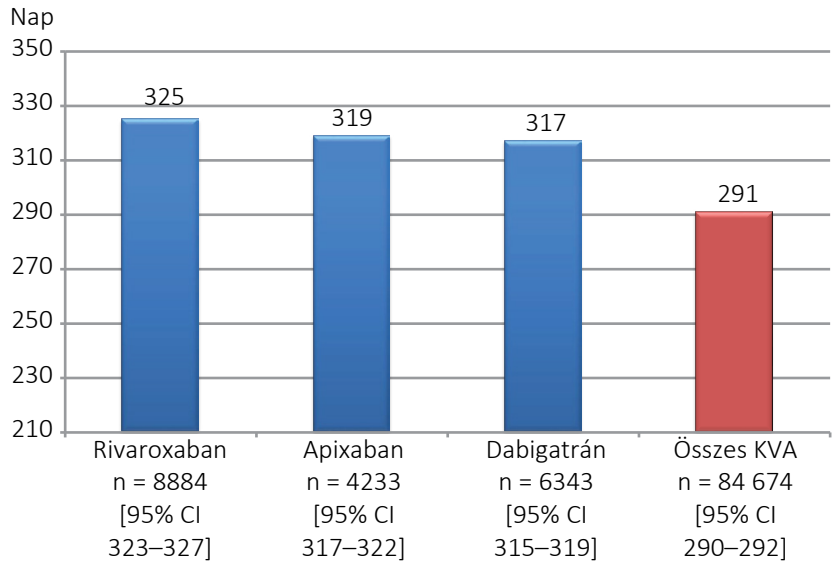

8. ábra

A gyógyszerszedés átlagos ideje a már OAK-kal (NOAK-hatóanyagok és KVA) kezelt betegeknél $(\mathrm{n}=104220)$

$\mathrm{CI}=$ konfidenciaintervallum $; \mathrm{KVA}=\mathrm{K}$-vitamin-antagonista $\mathrm{NOAK}=$ új orális antikoaguláns; OAK = orális antikoaguláns

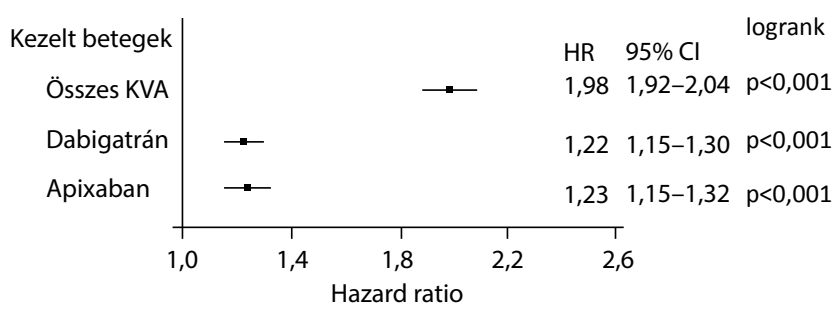

9. ábra

Az OAK-terápia elhagyásának kockázata az előzetesen már OAK-kal kezelt betegeknél $(\mathrm{n}=104220$; referencia $[\mathrm{HR}=$ $1,00]$ a rivaroxaban)

$\mathrm{CI}=$ konfidenciaintervallum $; \mathrm{HR}=$ kockázati arány $; \mathrm{OAK}=$ orá lis antikoaguláns

kockázata mindkét betegcsoportban mintegy kétszeres volt a NOAK-terápiához képest. Az egyes NOAK-hatóanyagok között különbségeket találtunk a betegadherencia vonatkozásában. Az újonnan NOAK-ot kezdőknél és a már NOAK-terápián lévők esetében egyaránt a rivaroxaban rendelkezett a legmagasabb egyéves perzisztenciával $(65,7 \%$, illetve $73,4 \%)$. A rivaroxabanhoz képest mindegyik más NOAK-hatóanyag elhagyásának szignifikánsan magasabb kockázatát találtuk mindkét betegcsoportban és bármely összehasonlításban (5. és 9. ábra).

Korábbi munkánkban [6], amelyben az orális antikoagulánssal már kezelt pitvarfibrilláló betegek egyéves terápiahúségét mutattuk be, a mostani dolgozatunkhoz hasonló bevonási kritériumok szerint, a 2015. év második felének kiindulópontjaként elemeztük a NEAK-adatokat. E vizsgálatunkban a mostanihoz hasonlóan azt igazoltuk, hogy a KVA-terápia egyéves terápiahúségét jelentősen felülmúlta a NOAK-terápia adherenciája. Ebben a dolgozatunkban is azt találtuk, hogy a rivaroxaban rendelkezett - a NOAK-hatóanyagok közül - a legjobb egyéves perzisztenciával.
Számos nemzetközi elemzésben is tanulmányozták az OAK-terápia adherenciáját. Egy egyesült államokbeli adatbázis (Truven Health Analytics MarketScan) 20122014. évi adatainak felhasználásával a korábban OAKterápia-naiv PF-betegek NOAK-vény-kiváltási adatait elemezték. A szerzők a betegek 9 hónapos követése után a rivaroxaban és az apixaban esetében egyaránt 66\%-os, míg a dabigatránt szedőknél 57\%-os adherenciát igazoltak, amely a dabigatránhoz képest szignifikánsan $(\mathrm{p}<0,001)$ jobbnak bizonyult [10]. Ugyanennek az adatbázisnak egy frissen közölt másik feldolgozásában, a 2009 és 2015 közötti időszakot tanulmányozva elemezték a korábban terápianaiv PF-betegek NOAK-szedési szokásait. Itt az apixaban 12 hónapos adherenciáját 70\%nak, a rivaroxabanét 64\%-nak, míg a dabigatránét 57\%nak találták [11].

Az elmúlt években a NOAK-ok bevezetésével lényegesen egyszerűsödött PF-betegeink antikoaguláns-terápiája [12], mivel a KVA-kezeléssel szemben - amelynél számos nehézséget okoz a rendszeres INR-ellenőrzés, a dózis gyakori változtatása, a táplálék K-vitamin-tartalmának nyomon követése stb. - az új orális antikoagulánsok egyszerû alkalmazása számos előnnyel jár. Ez megnyilvánul a hatásosság mellett a biztonságossági profilban és nem mellékesen a terápiahűség vonatkozásában is. Bár a hazai NOAK-adherencia-adatok örvendetesen egyre inkább konvergálnak a nemzetközi eredményekhez, ennek ellenére még mindig számos a teendő a PF-betegek terápiahüségének javítása terén.

\section{Korlátok}

- Vizsgálatunk limitációja volt, hogy a NEAK vénykiváltási adatbázisának retrospektív analízise során nem tudtuk vizsgálni a primer nonadherenciát.

- A perzisztenciaadatok az adatbázisunkban csak összesítve voltak elérhetők, ezért a bevonási időszak során eltérő időpontokban bevont betegek ugyanúgy egyéves perzisztenciába tartoztak, és ezért a vizsgálati periódus alatt a terápiahüséget esetlegesen befolyásoló tényezőket nem tudtuk figyelembe venni.

- Fontos módszertani limitáció volt, hogy a terápiahüséget potenciálisan befolyásoló tényezőkről nem állt rendelkezésünkre adat.

- Az edoxaban 2016. július 1-tól került forgalomba, de támogatott formában nem volt elérhető PF-ban, ezért elemzésünkben nem szerepelt.

- A vényforgalmi adatok csak egy betegség rögzítésére alkalmasak, de jelentős lehet azon betegek száma, akiknél pitvarfibrilláció áll fenn (I48H0), és múbillentyưvel élnek, emiatt csak KVA-kezelés jön szóba esetükben, ezért a vényforgalmi adatok önmagukban nem jelentettek e szempontból teljesen homogén betegcsoportot.

- Vizsgálatunk limitációja volt, hogy a NOAK-kezelés finanszírozási protokolljában az előzetes KVA-kezelés feltételként szerepel, így a kényelmesebb és sok szem- 
pontból előnyösebb NOAK-terápia bevezetése értelemszerúen csökkenti a KVA-terápia húségét.

- Az esetek egy részében előfordulhat, hogy az OAK indikációjául szolgáló betegség szanálódik (például paroxizmális pitvarfibrilláció után tartósan sinusrhythmus áll fenn), és egy bizonyos idő múlva a kezelőorvos elhagyja az OAK-terápiát. Ez is csökkenti a vényforgalmi adatokra támaszkodó perzisztenciát.

Anyagi támogatás: A szerzők nem részesültek anyagi támogatásban a közlemény, illetve a kapcsolódó kutatómunka során.

Szerzői munkamegosztás: S. G.: A vizsgálat hipotézisének kidolgozása, az adatgyüjtés megtervezése, a kézirat megszövegezése. P. A.: A vizsgálat adatainak statisztikai feldolgozása, az ehhez kapcsolódó módszerek ismertetése, a kézirat szövegezése. V. R., M. M.: A kézirat megszövegezése. A cikk végleges változatát mindegyik szerző elolvasta és jóváhagyta.

Érdekeltségek: A szerzőknek nincsenek érdekeltségeik.

\section{Köszönetnyilvánítás}

A szerzők köszönetet mondanak a MedicalScan Kft.-nek a Nemzeti Egészségbiztosítási Alapkezelő adatbázisának szakszerű lekérdezéséért.

\section{Irodalom}

[1] Steffel J, Verhamme P, Potpara TS, et al.; ESC Scientific Document Group. The 2018 European Heart Rhythm Association Practical Guide on the use of non-vitamin K antagonist oral anticoagulants in patients with atrial fibrillation. Eur Heart J. 2018; 39: 1330-1393.

[2] Kirchhof P, Benussi S, Kotecha D, et al.; ESC Scientific Document Group. 2016 ESC guidelines for the management of atrial fibrillation developed in collaboration with EACTS. Eur Heart J. 2016; 37: 2893-2962.

[3] Szegedi A, Csanádi Z. The efficacy and safety of edoxaban in non-valvular atrial fibrillation. [Az edoxabán véralvadásgátló hatásossága és biztonságossága nonvalvuláris pitvarfibrillációban.] Orv Hetil. 2018; 159: 466-469. [Hungarian]

[4] Tomcsányi J, Bózsik B, Rokszin Gy, et al. The prevalence of atrial fibrillation in Hungary. [A pitvarfibrilláció prevalenciája Magyarországon.] Orv Hetil. 2012; 153: 339-342. [Hungarian]

[5] Shore S, Carey EP, Turakhia MP, et al. Adherence to dabigatran therapy and longitudinal patient outcomes: insights from the veterans health administration. Am Heart J. 2014; 167: 810817.

[6] Simonyi G, Ferenci T, Finta E, et al. One-year persistence of patients already treated with oral anticoagulants for atrial fibrillation. [Orális antikoagulánssal már kezelt pitvarfibrilláló betegek egyéves terápiahúsége.] Orv Hetil. 2019; 160: 509-515. [Hungarian]

[7] Singer JD, Willett JB. Applied longitudinal data analysis: modeling change and event occurrence. Oxford University Press, New York, NY, 2003.

[8] Mills M. Introducing survival and event history analysis. Sage Publications, London, 2011.

[9] Willett JB, Singer JD. Investigating onset, cessation, relapse, and recovery: why you should, and how you can, use discrete-time survival analysis to examine event occurrence. J Consult Clin Psychol. 1993; 61: 952-965.

[10] Brown JD, Shewale AR, Talbert JC. Adherence to rivaroxaban, dabigatran, and apixaban for stroke prevention for newly diagnosed and treatment-naive atrial fibrillation patients: an update using 2013-2014 data. J Manag Care Spec Pharm. 2017; 23: 958-967.

[11] Pham PN, Brown JD. Real-world adherence for direct oral anticoagulants in a newly diagnosed atrial fibrillation cohort: does the dosing interval matter? BMC Cardiovasc Disord. 2019; 19: 64.

[12] Kiss RG. Direct oral anticoagulants in cardiology. [Direkt orális antikoagulánsok a kardiológiában.] Orv Hetil. 2016; 157: 1507-1510. [Hungarian]

(Simonyi Gábor dr., Budapest, Tétényi út 12-16., 1115 e-mail: bmbel3@gmail.com)

\section{"Necessitati quodlibet telum utile est." (Nincs semmi, ami a szükség kezében ne lenne fegyverré.)}

A cikk a Creative Commons Attribution 4.0 International License (https://creativecommons.org/licenses/by/4.0/) feltételei szerint publikált Open Access közlemény, melynek szellemében a cikk bármilyen médiumban szabadon felhasználható, megosztható és újraközölhető, feltéve, hogy az eredeti szerző és a közlés helye, illetve a CC License linkje és az esetlegesen végrehajtott módosítások feltüntetésre kerülnek. (SID_1) 